\title{
THE REFERENDUM - BETWEEN FREEDOM AND CONSTITUTIONALITY
}

DOI: $10.47743 /$ rdc-2018-1-0002

Verginia VEDINAS'

\section{Summary}

The study aims to analyze the legal status of the referendum in general and, in particular, of the one organized by the President under Art. 90 of the Constitution and by the local public administration authorities, according to the principle of consulting the population in solving particular problems of local interest.

The central issue, which goes as a "red thread", our approach, reffers to the issues that can be the subject of the two types of referendum and how "free" are the subjects of law that initiate them in determining the sphere of issues that are the subject of this sphere. The conclusion we have reached is that such freedom is not unlimited, that it stops where the Constitution says, and the fundamental principles it enshrines, being unable to be the subject of a referendum, national or local, issues forbidden by the Basic Law.

Keywords: referendum; national referendum; local referendum; freedom; limits; constitutionality; the sphere of problems; the rule of law; the supremacy of the Constitution

\section{Referendum, the direct method of exercising sovereignty}

From a terminological point of view, the word referendum has its origins in Roman law, where it represented the way of direct consultation of all citizens who had the right to vote.

Article 2 of the Constitution ${ }^{2}$, in the form resulting after its revisal, provides that "The national sovereignty shall reside within the Romanian people, that shall exercise it by means of their representative bodies, resulting from free, periodical and fair

\footnotetext{
${ }^{1} \mathrm{PhD}$, Faculty of Law, University of Bucharest, Member of the Court of Accounts of Romania, Accountant, Head of the Legal Department of the Court of Accounts.

2 The Romanian Constitution was published in the Official Gazette of Romania no. 233 of 21 November 1991. It was revised by Law no. 429/2003, published in the Official Gazette of Romania no. 758 of 29 October 2003 and republished in the Official Gazette of Romania M. Of. no. 767 of 31 October 2003.
}

\section{CONSTITUTIONAL LAW REVIEW}


elections, as well as by referendum". I have emphasized in the content of the text the part that was added by the Law of Revision no. 429/2003, considered necessary to guarantee the democratic origin of the representative organs through which national sovereignty is exercised by the Romanian people. In this regard, an author states that "This amendment to the text in Art. 2 paragraph (1) of the Constitution is determined by the requirement to specify that the representative authorities - the Parliament, the President of Romania, as well as the mayors and local councils (and the county councils, we add) - are democratically appointed through free, periodic and fair elections" 3 .

It should be kept in mind that the exercise of sovereignty through representative bodies is an indirect method, which also has, at the same time, the nature of a rule in the functioning of the Statea of law, except for those in which the referendum is held for any decision, at the territorial level, at the level of narrower or more extensive territorial communities ${ }^{4}$.

The referendum represents "the most effective and clear way of direct consultation of the will of the population" ${ }^{5}$, and a way of attaining the balance of a democracy, including the "timing" of the excesses to which the representative bodies and the governmental bodies often give in to, which gives the people, according to the authors cited, a role of "arbitrator" in making important decisions, which look at the present but, above all, its future.

There are several types of referendums. Thus, we identify what the doctrine calls a constitutional referendum, which is mandatory in nature ${ }^{6}$. Another type of referendum which concerns the adoption of a law, the legislative referendum ${ }^{7}$ and lastly the referendum with a consultative nature, which is optional.

The Fundamental Law enshrines several articles, which, in the language of the French School, we can qualify as constitutional bases for the referendum, in particular Articles 2 par. (1); art. 73 par. (3) letter d) ${ }^{8}$; art. 909; art. 95 par. (3) ${ }^{10}$; art. 146 lett. i $)^{11}$ and art. 151 par. $(3)^{12}$, from the analysis of which we can identify the following dimensions of the legal regime of this institution:

\footnotetext{
${ }^{3}$ C. Ionescu, Constituția României, Legea de revizuire comentată şi adnotată cu dezbateri parlamentare, All Beck Publishing House, Bucharest, 2003, p. 8.

4 The most famous case is represented by Switzerland, where no decision is made if the referendum has not previously been expressed by the people.

5 I. Muraru, E.-S. Tănăsescu, în I. Muraru, E.-S. Tănăsescu (coord.), Constituția României, Comentariu pe articole, C.H. Beck Publishing House, Bucharest, 2008, pp. 25-26.

${ }^{6}$ Art. 115 para. (3) states that "the review shall be final after its approval by referendum, held no later than 30 days after the adoption of the draft or the proposal for revision".

${ }^{7}$ I. Vida, Puterea executivă şi administrația publică, Regia Autonomă “Monitorul Oficial”, Bucharest, 1994, p. 64.

${ }^{8}$ According to this text, the organization and conduct of the referendum are regulated by organic law.

${ }^{9}$ Regulates the referendum organized by the President.

10 The text regulates the referendum organized for the dismissal of the President in case of his suspension from office.

${ }^{11}$ According to this text, among the attributions of the Constitutional Court, it is also found that it guards the observance of the procedure for organizing the referendum and confirms its results.

${ }^{12}$ According to the text, the revision of the Constitution is final, after its approval by referendum, held no later than 30 days after the adoption of the procedure or the proposal for revision.
}

STUDIES AND ARTICLES 
a) a method of exercising sovereignty, by its owner, the people. This is its defining feature, from which all that we enunciate further will result and to which they relate;

b) a way of consulting the people, prior to making fundamental decisions, to which all representative bodies at the central and local level, namely the President, the Parliament, can make use of in the case of the constitutional referendum; and the local public administration bodies in case of a local referendum. From this perspective, the referendum appears to us as a form of joint exercise of the two types of sovereignty.

c) a way of consulting the people in the case of the intervention of a form of responsibility applicable to the head of state, namely political or administrative-disciplinary accountability, by the procedure of suspension from office;

d) a stage in the process of adopting or amending the fundamental law.

We stop at these characteristics, as we are convinced that they can be further developed and we hope to determine approaches and represent a starting point in analyzing the legal status of this fundamental institution of the rule of law. Its significance results not only from the role conferred on it by the Constitution and the organic law through which its legal regime is developed ${ }^{13}$ and which has been the subject of several exceptions of unconstitutionality settled by the Constitutional Court ${ }^{14}$, but also by the establishment of the dual role for the Constitutional Court, to observe the procedure for organizing and conducting the referendum and to validate the results of the referendum. It is the same public authority, the guarantor of the supremacy of the Constitution, which exercises a similar function in the choice of one of the representative bodies at national level ${ }^{15}$, respectively the President ${ }^{16}$.

\section{The Referendum organized by the President: reflections and introspections}

Article 90 of the Constitution, entitled "referendum", enshrines one of the powers of the head of state, traditionally qualified by the doctrine, as part of the category of duties exercised in the relations with the people ${ }^{17}$.

According to this text, "The President of Romania, after consulting the Parliament, may ask the people to express their will on issues of national interest by referendum".

\footnotetext{
${ }^{13}$ It is about Law no. 3/2000, republished in The Official Gazette of Romania No 84 of 24 February 2000, as amended and supplemented.

${ }^{14}$ Example: C.C.R. Ruling no. 731 of July 102012 publisned in The Official Gazette of Romania no. 478 of July 12 2012, C.C.R. Ruling no. 334 of June 262013 publisned in The Official Gazette of Romania no. 407 of July 52013 , CCR Ruling no. 471 of November 142013 publisned in The Official Gazette of Romania no. 754 din December 4 2013.

15 The second organ, which has the character of a supreme representative body, is the Parliament.

${ }^{16}$ According to art. 146 lett. f) of the Constitution.

${ }^{17}$ A. Iorgovan, Tratat de drept administrativ, vol. II, ed. IV, All Beck Publishing House, Bucharest, 2005, p. 299.
} 
We find that, from the point of view of the scope of the issues that are to be the object of the referendum, art. 90 states that this is a matter of national interest.

The question is, what is the meaning of this sintagm, in the context in which, naturally, the constituent does not define it because it is not its role to define. Such a role, to clarify the semantics of their terms and their legal regime, is the doctrine and the jurisprudence of the Constitutional Court.

In this respect, by the Constitutional Court Ruling no. 567 of July 11, 2006 18 it was stated that "Article 90 of the Constitution establishes the exclusive competence of the President in determining issues of national interest that can be subjects of the referendum, even if parliamentary consultation is mandatory. Only the President of Romania has the right to decide the issues of national interest and, within them, to establish, by decree, the concrete issue which is subject to the referendum and the date of its implementation".

As far as we are concerned, we appreciate that the President's right to determine the scope of the issues to be the subject of the referendum is exclusive, insofar as it relates to the Constitution, being in fact "limited" by the Fundamental Law. Thus, we consider that the The President can not submit to the referendum a problem which he considers to be "of national interest", but which by its content it contravenes the Constitution and even leads to a change "through the back door" of it. This, in our opinion, was the occasion for organizing the only referendum after the entry into force of the Constitution, namely the referendum which had as its object the people to answer two questions, if they agree to reduce the number of MPs to 300 and with reducing the number of Chambers of Parliament from two Chambers to a single one and thus moving from parliamentary bicameralism to unicameralism. The referendum was held on the same day as the presidential election.

In our opinion, the organized referendum, in terms of the sphere of the issues that the people were consulted, was useless on the first issue and unconstitutional with regard to the second issue.

With regard to the unconstitutional character of this referendum, several arguments can be considered in the context of the consultation on the reduction of the number of Chambers of Parliament ${ }^{19}$.

A first and most important argument is that the Constitution is violated, the observance of which the President is called upon to watch.

Indeed, according to art. 80 par. (2) of the Constitution, "The President of Romania shall guard the observance of the Constitution and the proper functioning of the public

\footnotetext{
18 Publisned in The Official Gazette of Romania. no. 613 of July 142006.

${ }^{19}$ V. Vedinaş, Tratat de drept adminsitrativ, vol. I, Universul Juridic Publishing House, Bucharest, 2008, pp. 178-179.
} 
authorities". After this text, contained in the first sentence of the constitutional rule, the second sentence follows, according to which "To this effect, he shall act as a mediator between the Powers in the State, as well as between the State and society". I have emphasized, in the content of the text, the parts that are concerned in our commentary on the issue. We start with the sintagm "to this effect", which is either ignored or overcome easily or even "lightly", we might say. First of all, we emphasize that the role of the President as a mediator has as a goal both the mission to guard the observance of the Constitution and as well as guarding the obeservance of the proper functioning of the public authorities.

Secondly, we draw attention to the fact that the mediation function is accomplished, on the one hand, between state powers and, on the other hand, between state and society, the latter being represented by non-governmental bodies, by civil society, in all its forms of organization, of the people as a whole.

Corroborating the provisions of Art. 90 with those of art. 80 par. (2) of the Constitution, we believe that the referendum is one of the means by which the role of mediator between state and society of the President is achieved. It is supposed that the head of state decides to consult the people by referendum when he feels the need to clarify some things, to eliminate some tensions, to balance certain relations in society. But such a role can not eliminate the attribute of the President, to guard the observance of the Constitution. In other words, it is unacceptable for the President to consult the people by referendum on a matter that is not just contrary to the Constitution, but it defeats it entirely, putting people in a position to express themselves against the Constitution, to create constitutional norms by referendum. In this way, as we have already mentioned, the implicit amendment of the constitutional provisions, in violation of the procedure provided for in Title VII of the Constitution.

To these arguments, others can be added, such as the fact that bicameralism is tradition in Romania and in the democratic states, being superior to unicameralism;

Finally, it should not be overlooked that two political events were organized on the same day, which is contrary to the principles established by the Venice Convention for Democracy through Law.

We were glad to see that our vision is also shared by the "undergoing" researchers and we are even referring to students of the Faculty of Law who have published an interesting study in the Public Law Review that we co-ordinate with our well-known Professor Nicolae Popa ${ }^{20}$.

\footnotetext{
${ }^{20}$ See article written by students A. Bajdechi, Ş.-M. Sârbu, National Referendum initiated by the President of Romania - between conflict and mediation, in the Public Law Magazine no. 1/2017, pp. 170-184.
} 


\section{Consultation of the citizens from the administrative-territorial units}

\section{in solving the local problems of special interest}

The public administration in the territorial administrative units shall be organized and operate on the basis of principles provided by art. 120 of the Constitution, respectively decentralization, local autonomy and deconcentration of public services and the recognition of the right of national minorities to use their native language, in writing and orally, in their relations with the local public administration bodies and the deconcentrated public services of the ministries and other bodies of the central specialized administration.

In the development of constitutional norms, Law no. 215/2001 of the local public administration ${ }^{21}$, which by art. 2 par. (1) adds to the four constitutional principles, the legality, elegibility and consultation of citizens in solving local issues of particular interest. We find that the text enshrines the principle of self-standing principle of citizen consultation.

To this the provisions of art. 3 paragraph (3) of the same normative act are added, according to which "The provisions of para. (2) shall be without prejudice to the possibility of consulting the inhabitants by referendum or by any other form of direct participation of citizens in public affairs, according to the law". Please note that par. (2) of art. 3 stipulates that the public authorities through which the local autonomy in the communes is established, towns and counties, respectively the local councils, the mayors and the county councils, which are elected by universal, equal, direct, secret and freely expressed vote. The non-appointment of the president of the county council can be explained by the fact that he is not elected by direct vote, as is provided by the text, but by indirect vote.

By the norm of art. 3 par. (3) of the Law no. 215/2001, the consultation of the citizens appears to us as a limitation in the exercise of the competence of the deliberative and executive authorities of the local autonomy. In other words, the indirect exercise of sovereignty at local level, through representative bodies, does not exclude the use of direct means of achieving it by referendum.

Thus we find that we find a double legal consecration of this principle: one in the article concerning the sphere of principles (Article 2) and the other in the article which regulates the meaning of concepts and principles and the limits of their exercise.

In this context, the understanding of the principle of consultation is consistently reported in the doctrine of local autonomy, the authors considering it as a result of it or giving it substance ${ }^{22}$.

\footnotetext{
${ }^{21}$ Republished in the Official Gazette of Romania no. 123 of 20 February 2007.

22 D. Apostol Tofan, Drept administrativ, C.H. Beck Publishing House,, vol. I, ed. 4, Bucharest, 2018, pp. 325-326;

I. Nicola, Drept administrativ, "Lucian Blaga” University Publishing House, Sibiu 2007, p. 188.
} 
The regulation of the actual realization is found in Law no. 215/2001, as well as in Law no. $3 / 2000$ on the organization and conduct of the referendum, with subsequent amendments and completions. "Ignored by the panoply of constitutional institutions, omitted from the good recipes of governments, the referendum is now enshrined in almost all the constitutions of the world, favorably accepted by the most diverse political regimes, claimed by parties, especially those in opposition, used successfully in international societies as a sovereign arbitration mechanism in the political and territorial litigation between various states. In a word, the referendum is fashionable"23. It is, as is clear from the previous quotation, a frequent means of "regulating" public affairs at local, national and supranational level.

The law does not specify what is meant by the phrase "local issues of particular interest", leaving it to the appreciation of each administrative-territorial unit to appreciate this ${ }^{24}$. In fact, Art. 14 of this law stipulates that "the issues subject to the local referendum are established by the local or county councils, as the case may be, at the proposal of the mayor, respectively of the president of the County Council" (s.n.).

From the interpretation of this text, it appears that the right to determine the sphere of issues that are the subject of a popular referendum or of a consultation in general belongs to the local and county councils. In this way, the legislator wanted to give substance to local autonomy ${ }^{25}$. As in the analysis dedicated to the referendum governed by Art. 90 of the Constitution, we underline that this right can not be exercised indefinitely, and that the subject of the referendum can not be subject to issues going beyond the current constitutional and legal framework. In other words, as an example, the deliberative authorities of the territorial-administrative units can not be consulted in any form whatsoever, on the issue of renouncing the use of the Romanian language in the local administration and the exclusive use of the language of a minority that has a significant share. This, because Romanian is an official language, according to art. 13 of the Constitution and the conditions in which the language of a national minority with a significant weight is used are stipulated in the Constitution and Law no. $215 / 2001$. Equally, it is forbidden to consult on the possibility of signing an employment contract in a field (eg agricultural) at the age of 14, provided that labor law provides that it can only be employed for 16 years and with the approval of the parent or guardian at the age of $15^{26}$.

From such a perspective, we appreciate that it is not possible to subject to a local referendum the issue of declaring the autonomy of a part of the territory of a state

\footnotetext{
${ }^{23} \mathrm{~S}$. Belaid, Essai d'une théorie générale de referendum, in Referendum et democratie, Ed. Presses de l'Universite des sciences sociales de Toulouse, 1998, p. 32, apud L.F. Ușvat, Pro sau contra referendumului, în The Law Review no. 3/2008, p. 64.

${ }^{24}$ L. Giurgiu, A. Segărceanu, C.H. Rogoveanu, Drept administrativ, ed. 2, Sylvi Publishing House, Bucharest, 2001, p. 39 .

${ }^{25}$ I. Nicola, Drept administrativ, op. cit., p. 188.

${ }^{26}$ We have in mind Art. 13 of the Labor Code, approved by Law no. 53/2003, republished in M. Of. no. 345 of 18 May 2011.
} 
proclaimed unitarily and nationally by the Constitution, such as Romania or Spain. Regarding Romania, the permanent steps being taken by representatives of a certain ethnic group to declare the autonomy of an area within the territory of the country, self-proclaimed Szekler Land, consisting of the three counties, Harghita, Covasna and Mureş ${ }^{27}$. The situation in Spain, created by the Catalonia autonomy referendum, is now strictly up to date not only for the Kingdom of Spain but also for the whole of the European Union and the Member States. We say this because it is an example that can be followed and can be considered to legitimate similar approaches in other states. The territorial separation of states does not fit into the European philosophy of construction. We therefore appreciate the need to express a position by the Venice Commission stating that referendums can only deal with issues that are in line with the Constitution.

To these arguments, we add, as far as Romania is concerned, that among the limitations of the revision of the Constitution there are also the provisions regarding the national, unitary and independent state character of the Romanian state. Thus, we understand that neither the derived constituent legislator is permitted to "touch" these norms, let alone be the subject of an indirect change by way of the referendum.

Consultation of citizens in addressing local issues of particular interest is an indispensable component for the functioning of local autonomy and is an essential element of semi-direct democracy, given that it offers local communities the opportunity to intervene directly to find solutions to problems that occur locally ${ }^{28}$.

A single mandatory referendum situation enshrines the organic law, namely if it is intended to change the territorial limits of the administrative-territorial units, which can be achieved only by law, based on the results of a local referendum.

Article 22 of Law no. 215/2001 provides that the territorial delimitation of communes, towns, municipalities and counties is established by law. Any change to their territorial limits may be made only by law and only after prior consultation of the citizens of the respective administrative-territorial units by referendum (s.n.), organized according to the law. Depending on the interest of the issue under the referendum, it may be organized throughout the administrative-territorial unit or only in certain subdivisions thereof.

The distinction between the mandatory and optional referendum operates in most of the European states that are engaged in local public administration reform, such as Hungary, the Czech Republic, Poland, Macedonia, Slovenia etc.

It is appropriate to make a distinction between the referendum, in the classical sense, which is the way of consulting the whole people, called upon to decide by

\footnotetext{
${ }^{27}$ It is about constantly finding, at the beginning of each parliamentary term, on the Parliament's agenda, a legislative initiative on the autonomy of the Szekler Land.

${ }^{28}$ Ş. Deaconu, La réforme de l'administration publique - facteur necessaire de l'adhésion de la Roumanie à l'Union Européenne, C. Călinoiu (coord.), La science du droit. Realités et perspectives (Collections d'études dediés au Professeur dr. Victor Duculescu), V.I.S. Print, Bucharest, 2004, p. 414.
} 
referendum on a bill of special importance or a matter of general interest, and the peoples' consultation, which represents a guiding element for the decisions of the local council or the county council, but which does not have a legally binding force, the local council being the one who will decide, as a deliberative authority, the form and content of that judgment ${ }^{29}$. The essence of the legal regime of the consultation is the obligation to go through it in order to know the opinion of the consulted law subject, without the result of the consultation itself producing legal effects.

The philosophy of associating local autonomy with the possibility of consulting citizens in solving issues of particular interest and prohibiting autonomy from affecting the right of residents to be consulted on local issues of particular interest is, in our view, a method to counterbalance between direct, participatory democracy and the representative one. Its significance also results from the fact that in most states of the world the referendum is constitutionally enshrined ${ }^{30}$. The referendum is considered to represent, by excellence, an instrument of direct democracy through which voters express their opinions and adopt a decision, usually of a normative nature directly ${ }^{31}$. It is thus an important instrument of democratic control of citizens, but also a tool to link them to the local public administration authorities in the period between the elections. They are thus at the confluence of several principles governing the organization and functioning of public administration, namely local autonomy, decentralization and deconcentration of public services ${ }^{32}$.

\section{Conclusions}

There is no doubt that "the call to the referendum must be encouraged and used as a means of consolidating the democratic process in a state and reducing the distance between the people and the decision-makers. Without denying its imperfections, the referendum represents, in the absence of modern philosophical innovations transformed into institutions to compete, a genuine form of self-government within democracy"33. The referendum has both virtues and deficiencies that should be taken into account responsibly without the latter reversing the important role that the Romanian legislator has also become aware of when devoting it to normative acts on state governance, in general and in the management of local communities in particular.

\footnotetext{
${ }^{29}$ E. Popa, Drept administrativ, Servo-Sat Publishing House, Arad. 2000, p. 71.

${ }^{30}$ With some exceptions, such as Belgium, the Netherlands, Malta.

${ }^{31}$ I. Muraru, E.S. Tănăsescu, Drept constituțional şi instituţii politice, vol. II, C.H. Beck Publishing House, Bucharest, 2009, p. 140.

32 M.C. Apostolache, Aspecte privind răspunderea juridică a primarului, in RDP no. 2/2011, p. 71.

${ }^{33}$ L.F. Uşvat, Pro sau contra referendumului, art. cit., p. 72.
} 